\title{
The first definitive record of the giant larvacean, Bathochordaeus charon, since its original description in 1900 and a range extension to the northeast Pacific Ocean
}

\author{
R. E. Sherlock, K. R. Walz and B. H. Robison
}

\begin{abstract}
Background: Larvaceans in the genus Bathochordaeus are large, often abundant filter feeders found throughout much of the world ocean. The first described species, Bathochordaeus charon, was reported over 100 years ago by Chun. However in the time since, few specimens have matched Chun's original description, resulting in ambiguity on the validity of $B$. charon as a species.
\end{abstract}

Methods: Specimens of Bathochordaeus charon were identified based on morphological traits, molecular data and observations made on high definition video.

Results: The first records of Bathochordaeus charon from the northeast Pacific Ocean off central California and Oregon, USA are reported. Morphology and molecular data clearly distinguish B. charon from its congener, B. stygius.

Conclusions: This paper establishes the first review of Bathochordaeus charon since its original description, extends the range of this species to the northeast Pacific Ocean, and provides the first molecular evidence for two species of Bathochordaeus.

Keywords: Appendicularian, Giant larvacean, Larvacean, Molecular, Monterey Bay, Morphology, Oikopleuridae, Taxonomy, Tunicata, Urochordata

\section{Background}

Chun (1900) provided the first description of a very large larvacean from specimens collected during the Valdivia expedition (1898-1899). He named the new species Bathochordaeus charon after the mythical figure who ferries the souls of the dead across the river Styx. During the Valdivia expedition two individuals were collected from the South Atlantic and two smaller specimens, from the Indian Ocean. When he studied them later, Lohmann (1914) placed the two largest Valdivia specimens in the family Oikopleuridae. Garstang (1936) later referred to them as "veritable giants among Appendicularians, the depressed body being as large as a walnut and the broad tail almost 3 ins. in length" and

* Correspondence: robs@mbari.org

Monterey Bay Aquarium Research Institute (MBARI), Moss Landing, CA 95039, USA his comment may be responsible for them being referred to today simply as "giant larvaceans". The two smaller Indian Ocean specimens were not described until much later (Lohmann 1931). Not only were the Indian Ocean specimens smaller at $<20 \mathrm{~mm}$ total length, they appeared to differ appreciably from the larger specimens collected in the Benguela Current (Lohmann 1914; Lohmann 1931; Garstang 1936). When Garstang (1936, 1937) collected two specimens of Bathochordaeus in very good condition from surface waters near Bermuda, he at once observed that they differed appreciably from Chun's. Garstang's specimens were smaller in size than the two collected by Chun in the South Atlantic but similar in size to the larger of the two collected in the Indian Ocean. However, three features struck Garstang (1936, 1937) as different: the Bermuda specimens lacked the prominent "obconical gill-pouches" 
(spiracles), and the crop-like esophageal expansion of Bathochordaeus charon and they possessed an oikoplastic region that was more comparable to other oikopleurids than B. charon as described by Chun (1900) and Lohmann (1914).

Consequently, Garstang wondered if the original description was hampered by misinterpretation or poor preservation (Garstang 1936, 1937). He could not fathom a purpose for either the seemingly counter-productive funnel-shape of the spiracles or the improbable and capacious esophageal expansion. Having no access to the original specimens, and unable to account for the absence of these conspicuous features, Garstang somewhat reluctantly described a new species: Bathochordaeus stygius, and greatly expanded the slowly growing body of work surrounding these enigmatic animals (Garstang 1937).

Since its description, Bathochordaeus charon has appeared in the literature a few times (Thompson 1948; Bückmann and Kapp 1973; Barham 1979; Galt 1979; Castellanos et al. 2009; Lindsay et al. 2015), without specimen collections to accompany them. The lack of specimens combined with Garstang's (1937) concerns about the characteristic features in the original description, have cast doubt on the legitimacy of $B$. charon (Chun) as a species distinct from B. stygius (Garstang). The first probable record of B. charon since Chun (1900) appeared in 1948, from the Pacific Ocean off Australia, although it was a single, small (trunk $3.2 \mathrm{~mm}$, tail $7.5 \mathrm{~mm}$ ) specimen (Thompson 1948). Time passed and the lack of specimens caused Fenaux (1966) to synonymize the two species. Subsequently, the second potential specimen(s) of B. charon were collected by Galt (1979): five animals acquired during three cruises off southern California, that he called B. charon. Unfortunately, those specimens are no longer available and Galt may have used the name $B$. charon for all his specimens in lieu of $B$. stygius, since the latter was suggested to him as applying to juvenile specimens (Bückmann and Kapp 1975; Galt 1979 and pers. comm.) and Galt's specimens were on the order of 3-6 cm in total length. In his description of $B$. charon Galt wrote "The present specimens conform generally to published accounts of $B$. charon, detailed descriptions of which were given by Chun (1900), Lohmann (1931)), Garstang (1937 as B. stygius)," indicating that Galt likely deferred to Fenaux's synonomy of the species in referring to them all as $B$. charon. More recently, a specimen called $B$. charon was collected by Castellanos et al. (2009)) but no description was provided and, although a photograph was included neither the large spiracles nor esophageal expansion are visible. Lindsay et al, (Lindsay et al. 2015) provide an in situ ROV image of the house of "Bathochordaeus sp. A" observed off the Nansei Island chain of Japan, but the structure of the inner filter differs markedly from the $B$. charon and B. stygius we have observed, and that larvacean was not collected.

Giant larvaceans, like other species of larvaceans, use their oikoplastic cells to secrete complex filters or 'houses' that allow them to concentrate and feed on particles (Lohmann 1933; Alldredge 1977; Morris and Deibel 1993; Flood et al. 1998). A house consists of a large, diaphanous outer structure as well as a smaller, more convoluted and bi-lobed inner structure that functions as a filter. Together these serve to concentrate appropriately-sized food particles from the surrounding water. The outer part of the house excludes larger material that would clog the inner filter. Thus, the outer structure often acquires a covering of marine 'snow' that can alter its size and shape (Hamner and Robison 1992; Silver et al. 1998). The inner filter concentrates food particles of ingestible size and are ultimately connected to the animal's mouth via a tube made of the same material as the rest of the structure. However, the inner filter is less diaphanous and more stereotypical in shape, often retaining that shape long after the animal has left its house (Robison et al. 2005).

In situ, larvaceans in the genus Bathochordaeus are often visible from several meters away because their houses may span a meter in longest dimension (Hamner and Robison 1992; Robison et al. 2005). When Barham (1979) made the first observations of the occupied houses of large larvaceans he was diving by bathyscaph and saucer in the Pacific Ocean, off southern California and Mexico. He called them "giant" or "large" larvacean houses and inferred they were probably "Bathochordaeus charon". However, he recalled, "seeing at least five types of large larvacean houses" and gave "general descriptions of three types". It is not clear he thought all types belonged to $B$. charon. One animal was collected, identified by Donald P. Abbott as a "larvacean" and the specimen was subsequently lost. Intraspecific differences in Bathochordaeus' house structure were not known at the time. Resolving the shape of the spiracles and esophagus of Bathochordaeus spp. from the portholes of his submersibles seems unlikely, since the larvaceans themselves were often invisible. Barham's dives occurred 10 years prior to his publication and it seems more likely that he used the name B. charon because Fenaux (1966) had just synonomized the species and it was the correct name to use.

Almost 30 years after he synonymized the two species, Fenaux apparently acquired specimens collected by manned submersibles that proved to him the validity of both species (Fenaux 1993, 1998). Regrettably, he never published that proof and in the current literature it remains unclear if more than one species of Bathochordaeus exists (Hopcroft 2005; Flood 2005).

Using remotely operated vehicles (ROVs) we have carefully observed and collected B. charon (Chun) as well 
as B. stygius (Garstang). A combination of morphological features, house structures and molecular evidence clearly distinguish the two species and provide the first records of $B$. charon from Monterey Bay as well as off the coast of Oregon, expanding its range into the eastern North Pacific Ocean (Fig. 1).

\section{Methods}

Specimens were collected with MBARI ROVs (remotely operated vehicles) using either detritus samplers or gentle suction (Robison 1995), and preserved in $5 \%$ formalin buffered with sodium tetraborate. The measurements presented here were made on preserved specimens.

Prior to microscopy, specimens were rinsed in seawater then exposed to DAPI (4',6-diamidino-2-phenylindole) for $2 \mathrm{~min}$, then rinsed again before observation. The oikoplastic cells that generate the mucus feeding filters of Bathochordaeus are many times polyploid (Flood 2005). Since DAPI binds strongly to DNA and fluoresces brightly when illuminated with UV light (Russell et al. 1975), the preparation enhances contrast in the oikoplastic region of these animals. The oikoplastic region of Bathochordaeus is a monolayer of cells that undulate over the trunk - it is not flat. Wanting to preserve the animal we had for a type-specimen, we chose not to dissect it. Instead, we took images at 12 focal planes, then stacked them together using Adobe Photoshop CS 6. Micrographs were taken with an Olympus DP-71 camera, mounted to a Nikon SMZU dissecting microscope.

For molecular work, animals were frozen in liquid nitrogen and stored at $-80^{\circ} \mathrm{C}$ until extraction. DNA samples were extracted from tissue using the DNeasy Kit (Qiagen, Valencia, CA USA) according to the

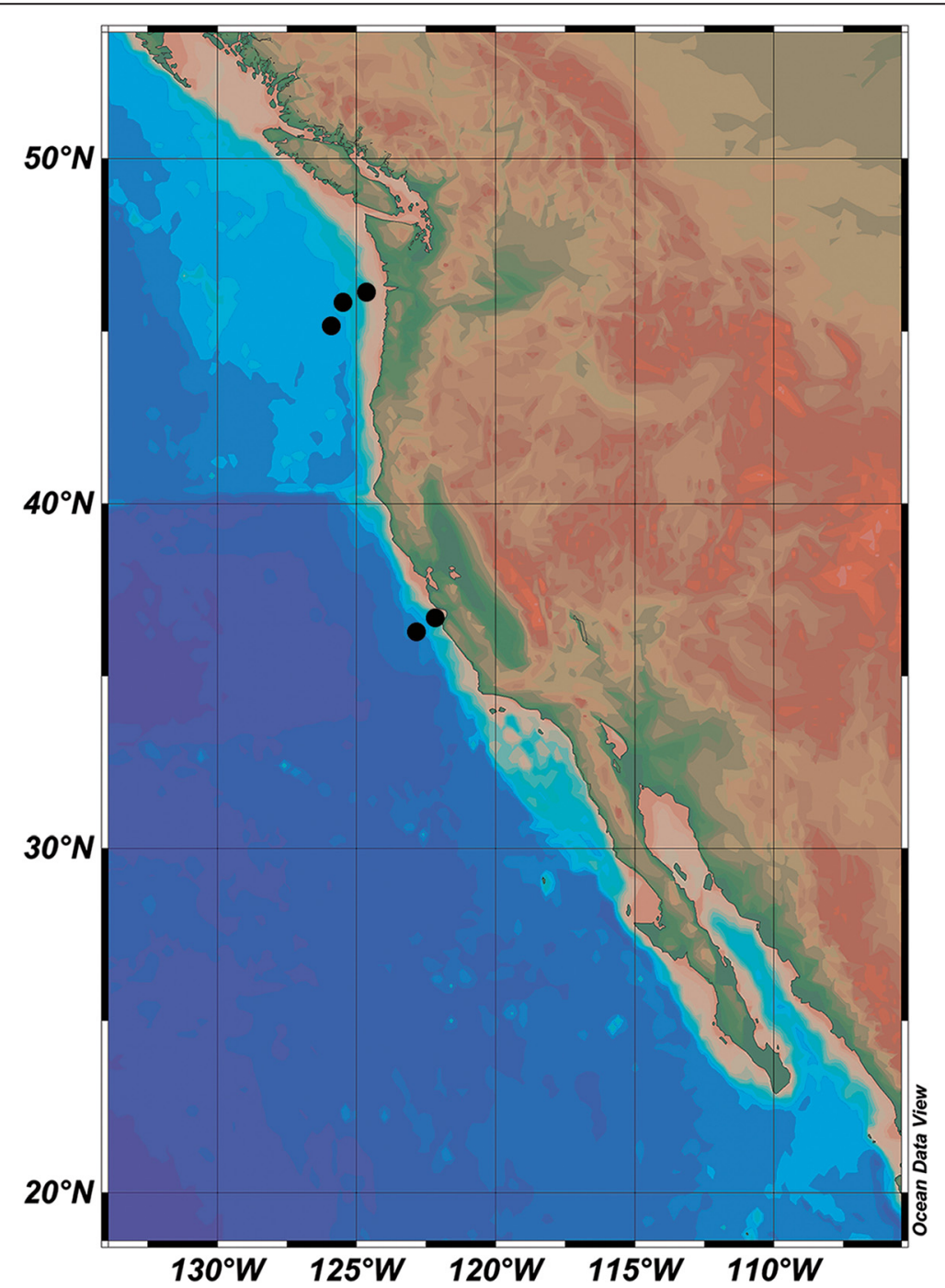

Fig. 1 The eastern North Pacific Ocean, with black circles marking the locations where Bathochordaeus charon has been observed and/or collected (for waypoints, see Table 1) 
manufacturer's instructions. Traditional DNA barcoding primers such as those for cyctochrome c oxidase 1 (Folmer et al. 1994), 12S, cytochrome b, and H3 did not amplify genes for Bathochordaeus spp. Instead we selected two primers used by Hirose and Hirose (2009), that were constructed specifically for tunicates, doliolids, salps and larvaceans:

\section{$5^{\prime}$ - CATTTWTTTTGATTWTTTRGWCATCC} NGA-3' (UroCox1-244 F)

$5^{\prime}$ - GCWCYTATWSWWAAWACATAATGAAAR TG-3' (UroCox1-387R).

These primers amplified a 400-base pair section of the mitochondrial cytochrome $\mathrm{c}$ oxidase subunit I gene (COI) with the following PCR parameters: 35 cycles of $94{ }^{\circ} \mathrm{C}$ for $1 \mathrm{~min}, 40^{\circ} \mathrm{C}$ for $1 \mathrm{~min}, 72^{\circ} \mathrm{C}$ for $1 \mathrm{~min}$. Amplification of an 1800-base-pair fragment of small subunit ribosomal DNA (18S) was conducted using the modified universal primers mitch $A$ and mitch $B$ from Medlin et al. (1988) with the following PCR parameters: 4 cycles of $94^{\circ} \mathrm{C}$ for $1 \mathrm{~min}, 58^{\circ} \mathrm{C}$ for 1 min stepping $0.1^{\circ} \mathrm{C} /$ second to $72{ }^{\circ} \mathrm{C}, 72{ }^{\circ} \mathrm{C}$ for $2 \mathrm{~min}$; followed by 29 cycles of $94{ }^{\circ} \mathrm{C}$ for $1 \mathrm{~min}, 64^{\circ} \mathrm{C}$ for $1 \mathrm{~min}, 72^{\circ} \mathrm{C}$ for 1:30 min (Medlin et al. 1988). All products were bi-directionally sequenced using BigDye ${ }^{\circ}$ Terminator v3.1 Cycle Sequencing Kit on an ABI 3100 or ABI3500 sequencer (Applied Biosystems, Foster City, CA USA). Sequences were edited and aligned using Geneious version 6.0.5 created by Biomatters (Auckland, New Zealand, http://www.geneious.com/), and submitted to GenBank (Accession Numbers: KT881543-KT881545). Genetic distance was calculated using p-distance model in MEGA v6.0 software (Tamura et al. 2013).
High definition (HD) video sequences of larvaceans taken by MBARI ROVs were used to compare the feeding structures ('houses') of B. charon and B. stygius as well as the morphology of the larvaceans occupying the houses.

\section{Material examined}

Physical descriptions of Bathochordaeus charon are based on two specimens collected in 2013 from Monterey Bay, CA (D457, D548): at $36.688795 \mathrm{~N}-122.043871 \mathrm{~W}$ and $36.540935 \mathrm{~N}-122.520577 \mathrm{~W}$; collection depth: $281 \mathrm{~m}$ and $598 \mathrm{~m}$ (Table 1). These specimens are now at the Smithsonian Institution's National Museum of Natural History (USNIM\# 1251907, 1251906). High definition (HD) video from the archive at the Monterey Bay Aquarium Research Institute (MBARI) provided records of 11 more individuals observed from 2006-2013, but not sampled (Table 1). Frozen tissue for molecular work came from two specimens collected in 2013 (D449, D548). A third specimen of $B$. charon, collected from Monterey Bay in 2007 was highly parasitized by ciliates and was not recognized initially as being different from $B$. stygius. This specimen was frozen for subsequent study of its symbionts.

\section{Comparative material examined}

No comparative material exists for Bathochordaeus charon. In lieu of the original specimens described by Chun (1900), figures from Aus Den Tiefen des Weltmeeres, the publication from the expedition of the Valdivia, are reprinted for comparison (Chun 1900).

Table 1 Specimens of Bathochordaeus charon collected or observed

\begin{tabular}{lllllll}
\hline Date & Dive \# & ROV & Depth $(\mathrm{m})$ & Lat. & Long. & Location or Smithsonian acquisition \# \\
\hline 24-Aug-2006 & 1024 & Tiburon & 293 & 46.15775 & -124.790794 & N/A \\
11-Jul-2007 & 3051 & Ventana & 236 & 36.692566 & -122.0462 & N/A \\
6-Aug-2007 & 1112 & Tiburon & 336 & 36.34012 & -122.90101 & MBARI \\
27-Jul-2009 & 54 & Doc Ricketts & 267 & 45.917487 & -125.499868 & N/A \\
29-Jul-2009 & 56 & Doc Ricketts & 233 & 45.151215 & -125.91437 & N/A \\
15-Mar-2010 & 3535 & Ventana & 255 & 36.748188 & -122.10306 & N/A \\
17-Mar-2010 & 3538 & Ventana & 135 & 36.69935 & -122.05209 & N/A \\
15-Apr-2010 & 146 & Doc Ricketts & 269 & 36.702025 & -122.047983 & N/A \\
18-Nov-2010 & 215 & Doc Ricketts & 286 & 36.747942 & -122.104007 & N/A \\
30-Mar-2011 & 3614 & Ventana & 297 & 36.750654 & -122.103026 & N/A \\
31-Mar-2011 & 3616 & Ventana & 281 & 36.732031 & -122.040878 & N/A \\
20-Sep-2011 & 3647 & Ventana & 261 & 36.69852 & -122.032776 & N/A \\
23-Mar-2013 & 449 & Doc Ricketts & 233 & 36.701236 & -122.060411 & MBARI \\
28-Mar-2013 & 457 & Doc Ricketts & 281 & 36.688795 & -122.043871 & 1251907 \\
11-Nov-2013 & 548 & Doc Ricketts & 598 & 36.540935 & -122.520577 & 1251906
\end{tabular}




\section{Results and discussion}

In March of 2013 a large and fecund specimen was hastily collected by the ROV Doc Ricketts as the vehicle was ascending for recovery. At the time, we assumed this large animal was Bathochordaeus stygius, a common local species. Since the larvacean spent less than $30 \mathrm{~min}$ in the detritus sampler, the individual remained in pristine condition and was preserved immediately, without microscopic observation. Some months later while making measurements, we realized that the larvacean was markedly different from B. stygius. Surprisingly, the specimen resembled Chun's (1900) original description of B. charon (Fig. 2).

\section{Morphology}

Key diagnostic features of Bathochordaeus charon are (letters in parentheses refer to structures in Figs. 2, 3 and 4):

- Two funnel-shaped spiracles with the inner, pharyngeal opening many times smaller than the outer, ventral opening (Fig. 3).

- A large expansion of the esophagus (Figs. 1, 2 and 3). The function is unknown, but size and position are reminiscent of a crop to aid in digestion.

- The oikoplastic regions of both B. charon and $B$. stygius have paired bands of 12 giant cells (fp), with much smaller trap cells ( $t$ ) just in front of them (Fig. 4). Garstang (1937) referred to these as "Lohmann's colloplasts" or "glandular crescents" and they are some of the largest and most conspicuous cells in the oikoplastic region. Both species also possess anterior paired bands consisting of eight cells (fa). In B. stygius the anterior cells are comparably sized to the posterior band. In B. charon the anterior bands of Fol's cells are so much smaller relative to the cells of the posterior bands that, on initial observation, the anterior bands may appear to be missing entirely or, perhaps to be a fourth row of trap cells (Fig. 4).

- The ciliated funnel (cf) is a conspicuous feature, located well to the right of the midline, off the upper wall of the pharynx and posterior to the mouth (Figs. 2, 3 and 4). From above or below, the cf of B. charon appears almost circular in shape. The apex of the funnel points left, back toward the brain, which is well-separated from the cf. The cf of B. charon is also well back from the dorsal lip and below the opening of the mouth. In contrast, the cf of B. stygius is located almost on the midline and only very slightly right of the brain. In B. stygius, the cf appears funnelshaped from above, is obscured from below, its apex is oriented posteriorly/backwards and the opening to the funnel lies directly under the dorsal lip, very close to the mouth (Fig. 4).

The granular texture of the $\mathrm{cf}$ is apparent in both species (Fig. 5) as are the movements of cilia in living specimens (online supporting video: Bathochordaeus_spp.mov).

- The position of the mouth is terminal, at least in larger specimens. In ventral view, the mouth extends beyond the anterior margin of the trunk, and the ventral oikoplastic region, such that it is visible from underneath. In B. stygius, the mouth is located well behind the anterior margin of the trunk (Fig. 4).

- The inner sensory cells of B. charon, just below the mouth, are relatively small compared to those of B. stygius (Fig. 5).
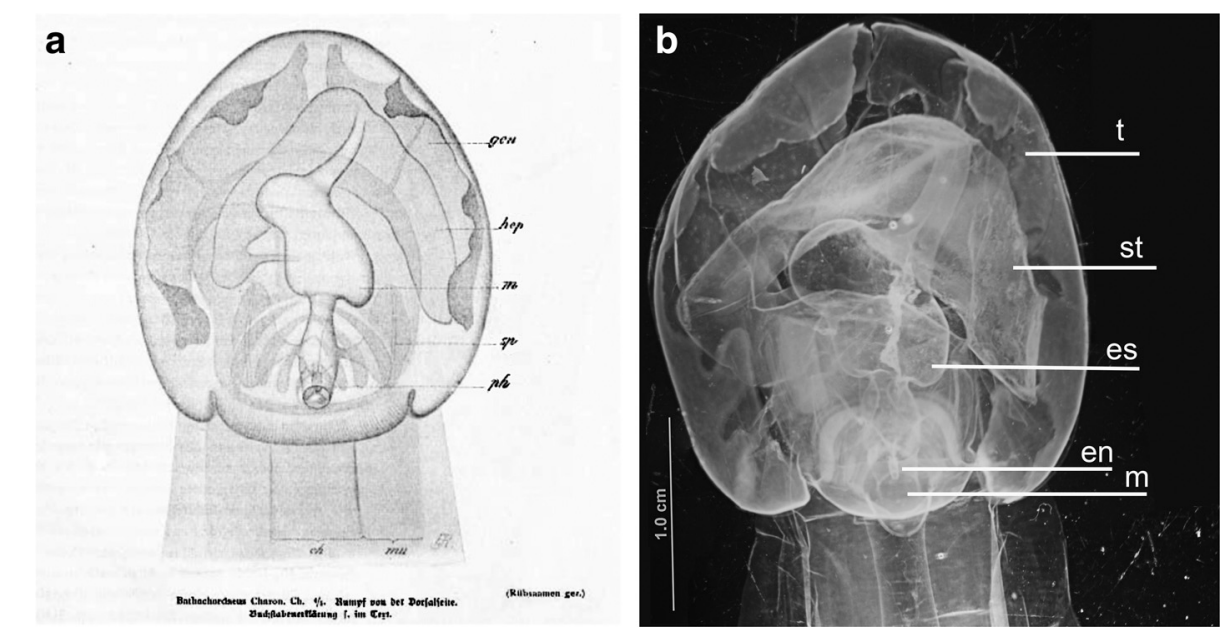

Fig. 2 Dorsal views of the trunk of Bathochordaeus charon. a. Drawing from Aus Den Tiefen des Weltmeeres, Chun's original account of the animal (left). b. Photo of B. charon collected 29 March, 2013 for comparison ( $m=$ mouth, en = endostyle, es = esophagus, st = left lobe of stomach, $\mathrm{t}=$ testis) 


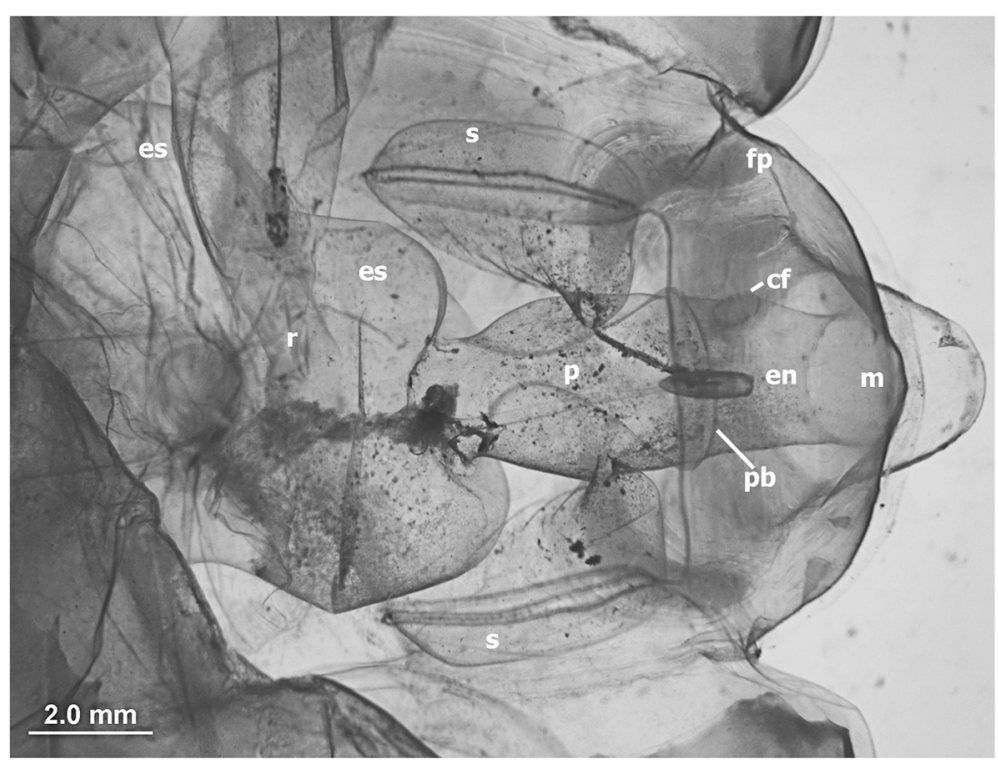

Fig. 3 Ventral view of the trunk of Bathochodaeus charon. The size of the external aperture of the spiracles $(\mathrm{s}=4.33 \mathrm{~mm})$ is more than 15 times the aperture $(0.27 \mathrm{~mm}$ ) that opens into the pharynx (p). The large, bag-like esophagus extends out the left side of the image (backwards). Note the large, flaccid intestine leading to the rectum $(r)$ and how the mouth, $(m)$, which opens dorsally, protrudes beyond the anterior margin of the trunk ( $\mathrm{pb}$ = peripharyngeal band, en = endostyle, $\mathrm{cf}=$ ciliated funnel, and $\mathrm{fp}=$ posterior giant cells of Fol's oikoplast)

- The intestine and rectum of B. charon are large and flaccid compared to the same structures in B. stygius (Fig. 3).

- The size of a larvacean is not diagnostic of species. We have only collected large $B$. charon (animals $>50 \mathrm{~mm}$ in total length). However, we have collected B. stygius that range from $11 \mathrm{~mm}$ to $87 \mathrm{~mm}$ in total length and there is no change in the relative size of their spiracles; i.e., the inner pharyngeal openings and outer openings to the spiracles of $B$. stygius are approximately equal in size regardless of the age/size of the specimen.

\section{Inner filter ('House') structure}

The pronounced morphological differences in the oikoplastic regions of $B$. charon and B. stygius suggest that the structural features of their houses may differ, particularly the inner filter (Fig. 4). The HD video taken by the Doc Ricketts immediately prior to the collection of $B$. charon was carefully reviewed and the differences in the inner filter as compared to that of B. stygius were readily apparent (Fig. 6).

The inner filter of $B$. charon is only slightly larger than the animals occupying the houses, whereas the inner filter of $B$. stygius is much larger than the occupant. The inner filter of $B$. charon is less convoluted and appears lumpy, more like a cluster of grapes than the manychambered and accordion-like structure made by $B$. stygius. In short, the relative size and appearance of the inner filters are characteristic for each species, with the inner filter of $B$. charon a distinctly simpler structure than that of $B$. stygius (online supporting video: Bathochordaeus_spp.mov and Fig. 6).

Once the differences in houses had been established by reviewing video from the first $B$. charon captured, all annotated video sequences for the genus Bathochordaeus were reviewed. Out of hundreds of larvaceans initially identified as B. stygius, eleven were determined to be $B$. charon based on clear, close-up, HD video footage of the houses and/or the spiracles. (Table 1 and Fig. 6).

\section{Molecular analyses}

Molecular analyses supported the morphological distinctions observed between $B$. charon and B. stygius. Of the 400 base pair region of COI that we amplified, the between-group distance was $16.9 \%$. For the $18 \mathrm{~s}$ gene, we compared one Bathochordaeus charon sequence to unpublished sequences of Bathochordaeus stygius from our studies. The sequences aligned with less than $0.5 \%$ differences among base pairs along the partial (1600-bp) segment of the $18 \mathrm{~S}$ gene. There were two base pair substitutions and one base pair deletion in B. charon. A comparison of the $18 \mathrm{~S}$ sequence of $B$. charon to sequences in GenBank using NCBI Blast revealed that $B$. charon had $97 \%$ identity to two larvaceans: Oikopleura dioica (AB013014) and Megalocercus huxleyi (FM244868).

\section{Conclusions}

Given that giant larvaceans may contribute up to one third of the vertical carbon flux to the deep seafloor in 

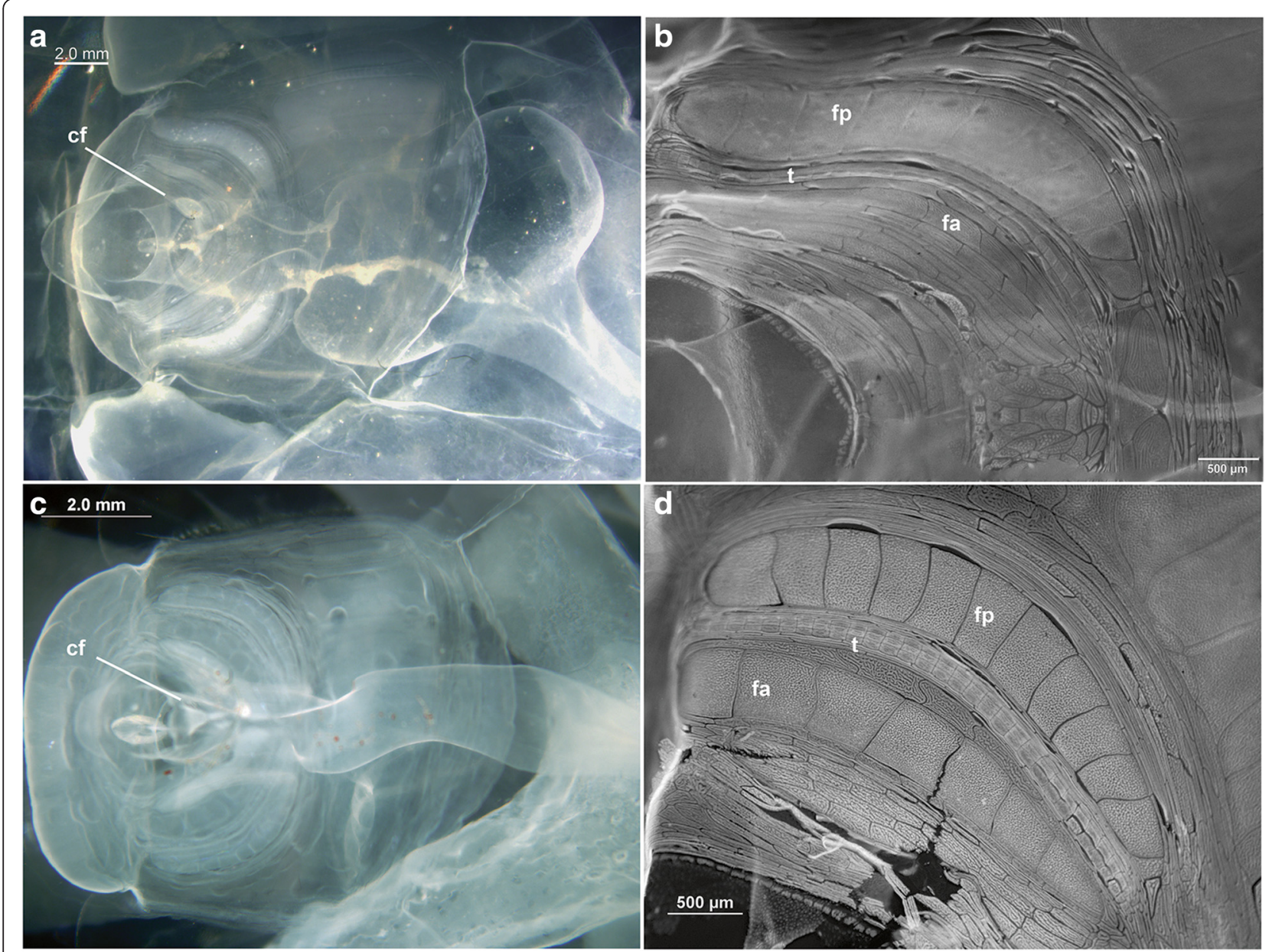

Fig. 4 The dorsal oikoplastic region of both species. Bathochordaeus charon (top) compared to B. stygius. The large esophagus of B. charon (a) is contrasted with the more slender and tubular esophagus of B. stygius (c). Plates B and D are magnified views of the right Fol's oikoblast from each specimen. Both species appear to have 12 large posterior Fol's cells (fp) with trap cells (t) just in front of them (b, d); however, the anterior row of Fol's cells $(\mathrm{fa})$ is greatly reduced in $B$. charon $(\mathbf{b})$

Monterey Bay (Robison et al. 2005) and that active houses are oases for commensal zooplankton in the mesopelagic habitat (Steinberg et al. 1994), resolving their identities is of ecological as well as taxonomic significance.

Nearly transparent and easily damaged, giant larvaceans are as enigmatic to look at under a microscope as are their descriptions in the literature. Their mouth opens dorsally while their rectum voids ventrally. Many of their structural features are so transparent as to be difficult to see, even under a microscope.

Two of Chun's most contested features of B. charon remain its odd, crop-like expansion of the esophagus, and its large, funnel-shaped spiracles constricted where they meet the pharynx. However, Chun's illustration is entirely accurate with regard to both features (Figs. 1, 2 and 3). The simplicity of the inner filter of B. charon almost certainly affects their ability to feed on particles. There are clearly more interstices in the inner filter of $B$. stygius (Fig. 6), which seem likely to be a consequence of
B. stygius' much larger bands of anterior Fol's cells (Fig. 5). And the twin supply passages to the inner filter, directly downstream from the tail chamber (tc) of B. stygius (Hamner and Robison 1992) appear conspicuously absent from the inner filter of B. charon (Fig. 6). If truly absent, it is a mystery how water is pumped through the inner filter. If present, the structure is so diminished as to be invisible in the video sequences we presently have for B. charon. Relative to body size, there is decreased surface area of their inner filter compared to that of $B$. stygius, and the seeming lack of split supply passages and the fragile, diaphanous structure suggests that the inner filter of B. charon may not generate or be able to accommodate the flow and pressure that the inner filter of $B$. stygius can sustain.

If true, this difference in flow through the house may provide some explanation for the "peculiar" triangular shape of the spiracles that so puzzled Garstang (1937). Larvacean spiracles draw food through the feeding tube 

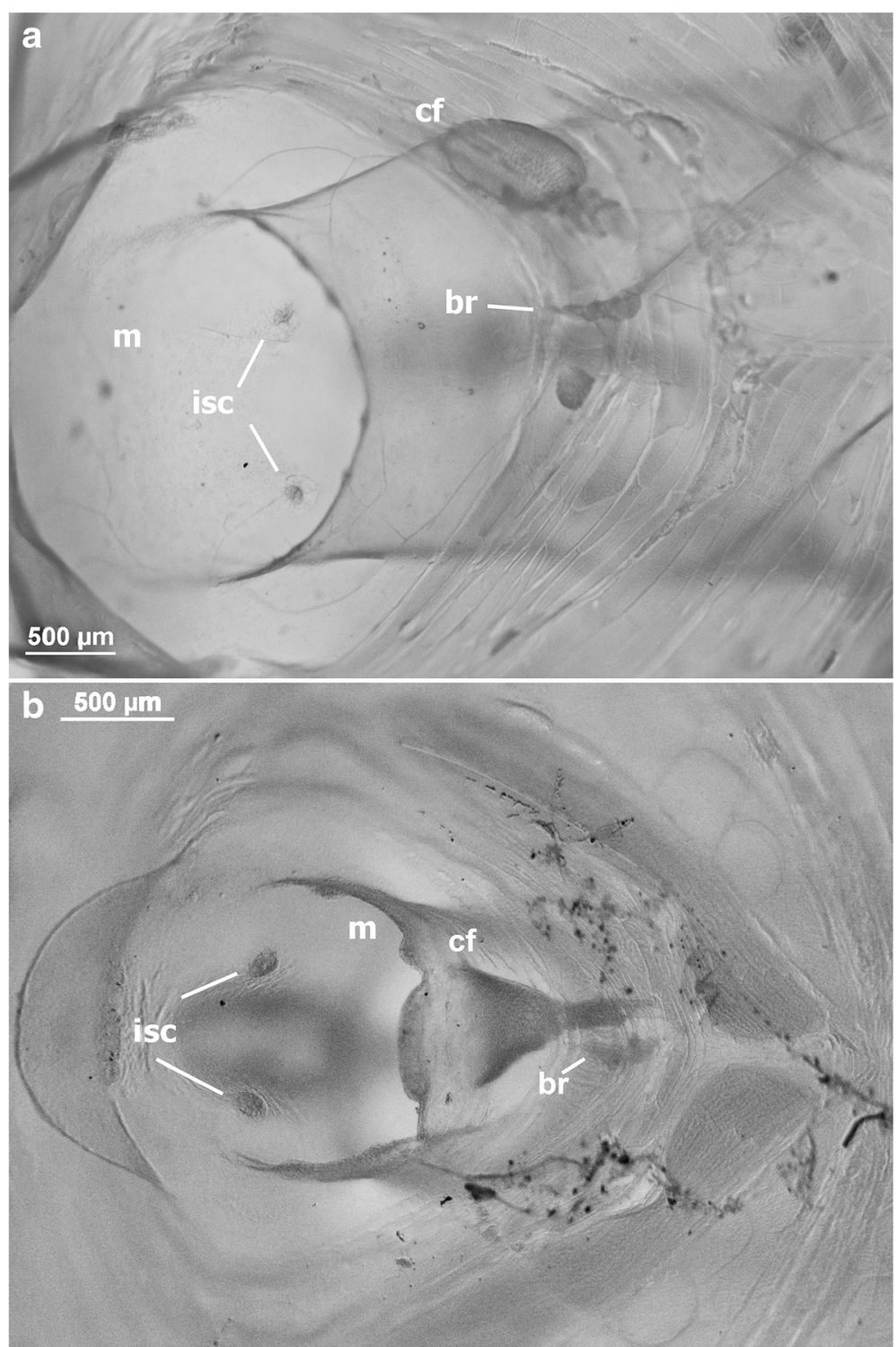

Fig. 5 Detail of the oral $(m=$ mouth) region Bathochordaeus charon (a), trunk width $225 \mathrm{~mm}$, and Bathochordaeus stygius (b), trunk width $126 \mathrm{~mm}$. The ciliated funnel (cf) is a conspicuous feature, and in $B$. charon lies well to the right side of the brain (br) while that of $B$. stygius is shifted almost to the midline. The inner sensory cells (isc) of $B$. charon are less conspicuous than those of $B$. stygius although $B$. charon is the larger individual

where the bi-lobed inner filter joins, and into the mouth (Deibel 1998). The large and densely ciliated external opening of the spiracles of $B$. charon could create a venturi that would help to pull water into the mouth (Fig. 3). Because the entry to the spiracles of $B$. charon is close to an order of magnitude smaller than the diameter of their mouth (Fig. 3), evacuating undesirable objects through their spiracles as do other oikopleurids (Alldredge 1977; Lombard et al. 2011), is not an option. If a particle enters the mouth, the only way out seems to be through the gut to the rectum.

A third point of confusion in the early literature came from Chun's assertion that $B$. charon had four pairs of
Fol's crescents, when in fact there are two pairs. Lohmann (1914) was also criticized by Garstang (1937) with regard to his description of the large and fairly conspicuous Fol's cells in B. charon. Garstang called these "glandular crescents" and because the anterior pair in B. stygius consists of eight giant cells, it was clear to him that those were "...identical with Fol's oikoplast in Oikopluera, Stegosoma, and Megalocercus both in structure and in position" (Garstang 1937). However, because Lohmann (1914) counted 12 giant Fol's cells in B. charon and asserted that only one pair of "glandular crescents" was visible, Garstang thought Lohmann had mistaken the 


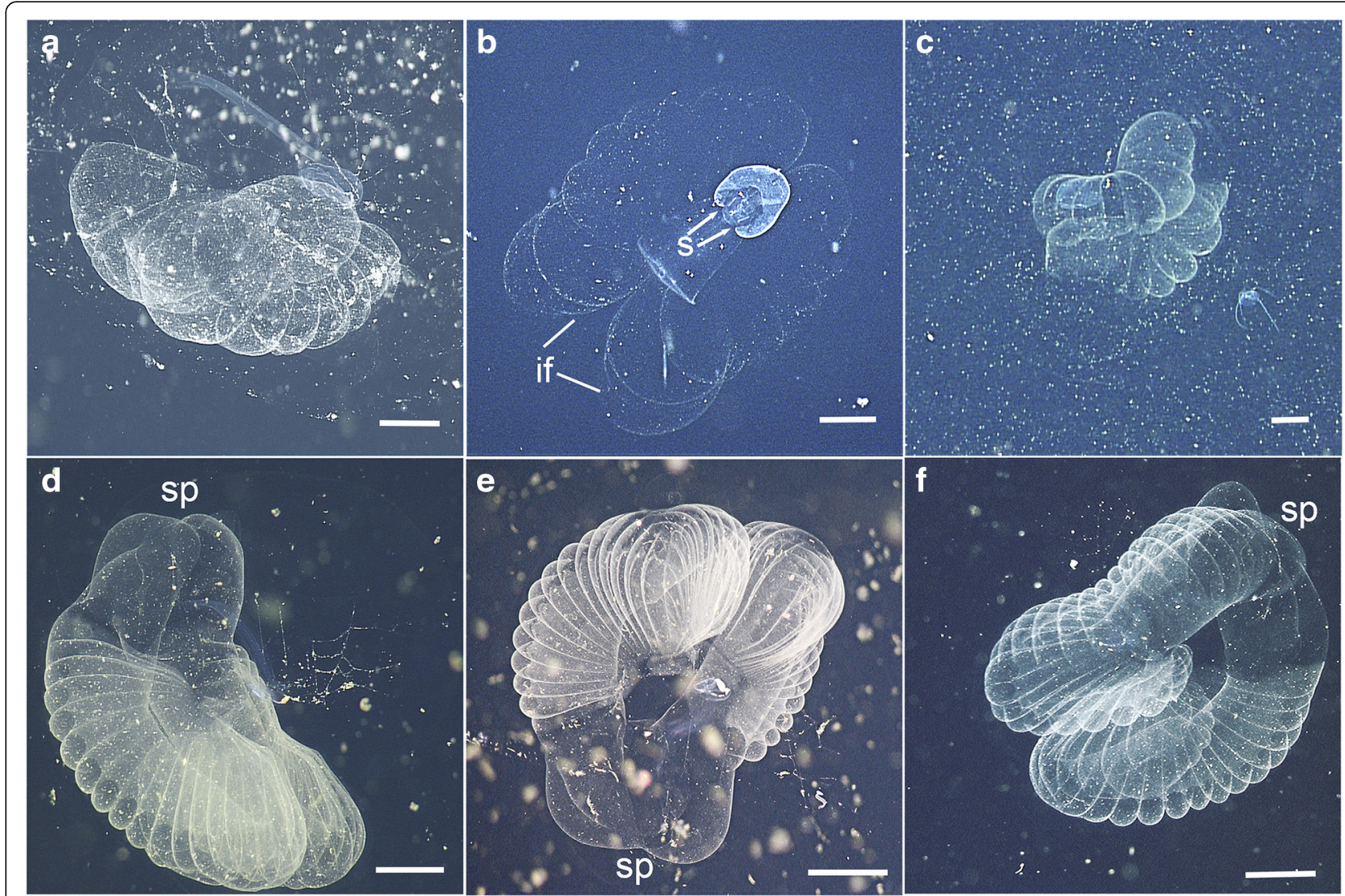

Fig. 6 The inner filter ("house") of Bathochordaeus charon (a-c) compared to B. stygius (d-f) are readily distinguishable in high-definition video, taken by MBARI ROVs. Bathochordaeus charon is larger in size relative to its inner filter (if) than is $B$. stygius, which also has more conspicuous supply passages (sp) through which water is diverted to either filter. The inner filter of $B$. charon is less convoluted than $B$. stygius and has fewer chambers (compare $\mathbf{c}$, f). Plate B demonstrates that the spiracles (s) can be seen on high-definition video. Scale bars $\sim 2 \mathrm{~cm}$, a-f

posterior giant cells (which were obvious in the specimens of $B$. stygius he collected) for Fol's cells and somehow missed the anterior crescent entirely. Although convinced that Lohmann had erred, Garstang proposed to call the larger, posterior crescent (which he maintained were not Fol's cells) 'Lohmann's colloplasts', in honor of Lohmann's lifetime of work with larvaceans. This terminology is ironic because in this regard, Garstang was incorrect.

Bathochordaeus charon clearly has one band of 12 giant cells on either side of the trunk as does $B$. stygius. But the anterior pair of 8 cells in B. charon are so small in comparison to those of $B$. stygius (which are comparable in size to the cells of the posterior band) as to appear missing. This difference in the anterior band of Fol's cells is probably why the inner filter of $B$. charon and B. stygius look so different (Fig. 6). Furthermore, we have observed the initial formation of many houses of $B$. stygius and both pairs of "glandular crescents", on either side of the trunk, make the inner filter. Therefore, we regard all of Garstang's "glandular crescents" as Fol's cells and distinguish each band based on its position on the trunk (i.e., anterior or posterior).
In over two decades of exploring the mesopelagic waters of Monterey Bay, CA, remarkably few Bathochordaeus charon $(n=15)$ were observed, while thousands of B. stygius have been encountered. Both species occupy a similar depth range in Monterey Bay, yet, based on the large differences in COI they are clearly not interbreeding populations. Moving forward we intend to look more closely at the diversity of larvaceans in the mesopelagic habitat, identifying these important organisms responsible for vertical transport of carbon through the water column. As of 2009, the recognized number of appendicularian species was 70, of which 43 are described for the $\mathrm{Pa}$ cific Ocean (Fenaux et al. 1998; Castellanos et al. 2009), Bathochordaeus charon unequivocally among them.

\section{Abbreviations}

\#, number; br, brain; cf, ciliated funnel; COI, cytochrome oxidase 1; en, endostyle; es, esophagus; et al., et alia, and others; fa, anterior cells of Fol's oikoplast; fp, posterior cells of Fol's oikoplast; HD, high-definition; i.e., id est, that is; isc, inner sensory cells; m, mouth; MBARI, Monterey Bay Aquarium Research Institute; N/A, not applicable; $p$, pharynx; pb, peripharyngeal band; $r$, rectum; ROV, remotely operated vehicle; sp, supply passages; st, left lobe of stomach; t, testis; VARS, video annotation and reference system 


\section{Acknowledgements}

We are grateful for the invaluable skills of our ROV pilots and ships' crews. The annotations and support of MBARI's video lab especially, Kyra Schlining and Susan Von Thun, were essential to this manuscript. Lynne Christianson, Shana Goffredi, and Shannon Johnson Williams helped in the early stages of the molecular work with equipment and advice to get us started. Chuck Galt, Russ Hopcroft, and Marsh Youngbluth provided valuable information and references. Thanks to Hans Jannasch for translating Chun's German to English. Kim Reisenbichler's help at sea and in the lab is indispensible. The comments by reviewers were helpful and improved this manuscript. This work is made possible through the generous support of the David and Lucile Packard Foundation.

\section{Funding}

The David and Lucile Packard Foundation.

\section{Availability of data and material}

The molecular dataset supporting the conclusions made in this manuscript is available in the GenBank repository: (https://www.ncbi.nlm.nih.gov/nuccore/) and the accession numbers KT881543-1545. Two specimens may be accessed through the Smithsonian Institution, National Museum of Natural History (Table 1). Video-based annotations of $B$. charon and their ancillary data are available from the Video Annotation and Reference System (VARS) at MBARI (http://www.mbari.org/products/research-software/video-annotationand-reference-system-vars/).

\section{Authors' contributions}

RES identified B. charon, made the morphological observations with input from all authors and wrote the first draft of the manuscript. KRW completed all molecular analyses and the majority of video annotations. BHR obtained funding and was responsible for all specimen collections. All authors contributed to editing the manuscript and have read and approved it.

\section{Competing interests}

The authors declare that they have no competing interests.

\section{Consent for publication}

All authors have read and agreed to the content of this manuscript and give consent for publication.

\section{Ethics approval and consent to participate}

Collections of Bathochordaeus charon specimens were made with a valid scientific collecting permit issued by the California Natural Resources Agency, Department of Fish and Wildlife (SC-2506).

\section{Received: 22 July 2016}

Published online: 30 August 2016

\section{References}

Alldredge AL. House morphology and mechanisms of feeding in the Oikopleuridae (Tunicata, Appendicularia). J Zool. 1977;181:175-88.

Barham EG. Giant larvacean houses: observations from deep submersibles. Science. 1979;205:1129-31.

Bückmann A, Kapp H. Untersuchungen am Zooplankton von der Atlantischen Kuppenfahrt der Meteor, März bis Juli 1967. Meteor Forschungsergebnisse D. 1973;13:11-36.

Bückmann A, Kapp H. Taxonomic characters used for the distinction of species of Appendicularia. Mitt Hamb Zool Mus Inst. 1975;72:201-28.

Castellanos IA, Morales-Ramírez A, Suárez-Morales E. Appendicularians (Urochordata). In: Wehrtmann IS, Cortés J, editors. Marine biodiversity of Costa Rica, Central America. Netherlands: Springer; 2009. p. 445-52.

Chun C. Aus den Tiefen des Weltmeeres. Jena: Gustav Fischer; 1900. p. 519-21.

Deibel D. Feeding and metabolism of Appendicularia. In: Bone Q, editor. The biology of pelagic tunicates. Oxford: Oxford University Press; 1998. p. 139-49.

Fenaux R. Synonymie et distribution géographique des appendiculaires. Bull Inst Océanogr Monaco. 1966;66(1363):1-23.

Fenaux R. The classification of Appendicularia (Tunicata): history and current state. Mem Inst Oceranogr: Monaco. 1993;17:1-123.

Fenaux R. Anatomy and functional morphology of the Appendicularia. In: Bone $\mathrm{Q}$, editor. The biology of pelagic tunicates. Oxford: Oxford University Press; 1998. p. 25-34.
Fenaux R, Bone Q, Deibel D. Appendicularian distribution and zoogeography In: Bone $Q$, editor. The biology of pelagic tunicates. Oxford: Oxford University Press; 1998. p. 251-64.

Flood PR. Toward a photographic atlas on special taxonomic characters of oikopleurid Appendicularia (Tunicata). In: Gorsky G, Youngbluth M, Deibel D, editors. Response of marine ecosystems to global change: ecological impact of appendicularians. Paris: Contemporary Publishing International; 2005. p. 59-85.

Flood PR, Deibel D, Morris C. The appendicularian house. In: Bone Q, editor. The biology of pelagic tunicates. Oxford: Oxford University Press; 1998. p. 105-24.

Folmer RH, Folkers PJ, Kaan A, Jonker AJ, Aelen J, Konings RN, Hilbers CW. Secondary structure of the single-stranded DNA binding protein encoded by filamentous phage Pf3 as determined by NMR. Eur J Biochem. 1994;224:663-76.

Galt CP. First records of a giant pelagic tunicate, Bathochordaeus charon (Urochordata, Larvacea), from the eastern Pacific Ocean, with notes on its biology. Fish Bull. 1979;77:514-9.

Garstang W. On a new Appendicularian, Bathochordaeus sp. from Bermuda, with a revision of the genus. P Linn Soc Lond. 1936;148(3):131-2.

Garstang W. On the anatomy and relations of the Appendicularian Bathochordaeus, based on a new species from Bermuda (B. stygius, sp. n.). J Linn Soc Lond Zoo. 1937;40:283-303.

Hamner WM, Robison BH. In situ observations of giant appendicularians in Monterey Bay. Deep-Sea Res. 1992;39:1299-313.

Hirose M, Hirose E. DNA barcoding in photosymbiotic species of Diplosoma (Ascidiacea: Didemnidae), with the description of a new species from the southern Ryukyus, Japan. Zool Sci. 2009;26:564-8.

Hopcroft RR. Diversity in larvaceans: How many species? In: Gorsky G, Youngbluth M, Deibel D, editors. Response of marine ecosystems to global change: ecological impact of appendicularians. Paris: Contemporary Publishing International; 2005. p. 45-57.

Lindsay D, Umetsu M, Grossmann M, Miyake H, Yamamoto $\mathrm{H}$. The gelatinous macroplankton community at the Hatoma knoll hydrothermal vent. In: Ishibashi J, Okino K, Sunamura M, editors. Subseafloor biosphere linked to hydrothermal systems. Japan: Springer; 2015. p. 639-66.

Lohmann H. Die Appendicularien der Valdivia expedition. Verh Dtsch zool Ges. 1914;24:157-92.

Lohmann H. Erste klasse der Tunicaten: Appendiculariae. In: Kükenthal W, Krumbach T, editors. Handbuch der zoologie. De Gruyter. Leipzig: De Gruyter, Berlin; 1933. p. 1-202.

Lohmann H. Die Appendicularien der Deutschen Tiefsee-Expedition. Wiss Ergeb Dtsch. Tiefsee-Exped. 1931;21:1-158.

Lombard F, Selander E, Kiørboe T. Active prey rejection in the filter-feeding appendicularian Oikopleura dioica. Limnol Oceanogr. 2011;56:1504-12.

Medlin L, Elwood HJ, Stickel S, Sogin ML. The characterization of enzymatically amplified eukaryotic 16S-like rRNA-coding regions. Gene. 1988;71:491-9.

Morris CC, Deibel D. Flow rate and particle concentration within the house of the pelagic tunicate Oikopleura vanhoeffeni. Mar Biol. 1993;115:445-52.

Robison BH. Light in the Ocean's midwaters. Sci Am. 1995;273:60-4.

Robison BH, Reisenbichler KR, Sherlock RE. Giant larvacean houses: Rapid carbon transport to the deep sea floor. Science. 2005;308:1609-11.

Russell C, Newman C, Williamson H. A simple cytochemical technique for demonstration of DNA in cells infected with mycoplasmas and viruses. Nature. 1975;253:461-2.

Silver MW, Coale SL, Pilskaln CH, Steinberg DR. Giant aggregates: Importance as microbial centers and agents of material flux in the mesopelagic zone. Limnol Oceanogr. 1998:43:498-507.

Steinberg DK, Silver MW, Pilskaln CH, Coale SL, Paduan JB. Midwater zooplankton communities on pelagic detritus (giant larvacean houses) in Monterey Bay, California. Limnol and Oceanogr. 1994;39:1606-20.

Tamura K, Stecher G, Peterson D, Filipski A, Kumar S. MEGA6: molecular evolutionary genetics analysis version 6.0. Molecular biology and evolution 2013:30:2725-29.

Thompson H. Bathochordaeus charon Chun 1900. In: Pelagic tunicates of Australia. Australia: Commonwealth Council for Scientific and Industrial Research; 1948. p. 1-196. 